\title{
PEROXISOME PROLIFERATOR-ACTIVATED RECEPTORS (PPARs) IN HEALTH AND DISEASE
}

\author{
Jiří Ehrmann Jr. ${ }^{\text {** }}$, Nicol Vavrušováa ${ }^{a}$ Yrjo Collan ${ }^{\text {, Zdeněk Kolára }}{ }^{a}$
}

aepartment of Pathology, Laboratory of Molecular Pathology, Faculty of Medicine, Palacký University, Hněvotinská 3,
Olomouc 77515, Czech Republic, e-mail: erman@tunw.upol.cz
b Department of Pathology, Faculty of Medicine, University of Turku, Kiinamyllynkatu 10, FIN-20520 Turku, Finland

Received: September 10, 2002

Key words: Orphan receptors / PPARs / Inflammation / Atherosclerosis / Cancer

Peroxisome proliferator-activated receptors (PPARs) belong to the superfamily of steroid-thyroid-retinoid nuclear receptors. PPARs are transcription factors activated by specific ligands and play an important role during cell signalling. Intensive study of PPARs during recent years has revealed their importance in both normal physiology and in the pathology of various tissues. They participate in the regulation of lipid metabolism, inflammation and the development of atherosclerosis or diabetes. They also play a role in the regulation of growth and differentiation of cancer. It has been suggested that PPAR ligands may have potent anticancer effects and therefore may serve as potential anticancer drugs. In this review we focus on a role of PPARs in breast cancer and in glial tumors of the brain.

Nuclear receptors are transcription factors activated by specific ligands which play an important role during cell signalling. They belong to the steroid-thyroid-retinoid receptor superfamily; these include receptors for steroids, thyroid hormone, vitamin A and D derived hormones and some fatty acids. Structurally, they share common features: highly conserved central DNA binding domain (binds receptor to specific DNA sequences Hormone Response Elements, HRE), ligand binding domain in the $\mathrm{COOH}$ - terminal region and variable N-terminal domain. Recently, the three-dimensional structure of DNA binding domains of various nuclear receptors have been described ${ }^{1}$. However, in some nuclear receptors the natural ligand (hormone) has not been identified and therefore the term "orphan" receptors (OR) was suggested a decade ago. Searching for such ligands (hormones) has introduced the concept of "reverse endocrinology". A typical example of this approach is the discovery of 9-cis retinoic acid (a metabolite of vitamin A) as a high-affinity ligand for three variants of retinoid X receptors (RXR). This in turn has led to better understanding of the processes regulated by retinoids ${ }^{3}$.

Currently, five families of OR are distinguished: 1. liver $\mathrm{X}$ receptor - LXR, 2. pregnane $\mathrm{X}$ receptor $\mathrm{PXR}, 3$. constitutive androstane receptor - CAR, 4. farnesoid X receptor $-\mathrm{FXR}$ and 5. peroxisome proliferatoractivated receptors - PPARs. LXR is an oxysterol receptor and regulates the catabolism of excess dietary cholesterol. PXR is activated by many compounds and by binding to a xenobiotic response element in the
CYP3A4 gene promoter serves as a xenobiotic sensor. The physiological role of CAR is not clear, however, although it is suggested that like PXR it may play a role in the regulation of steroid homeostasis. FXR is a nuclear bile acid receptor ${ }^{2,4}$.

Peroxisome Proliferator-Activated Receptors (PPARs) were first cloned from mouse liver in 1990 as the nuclear receptor mediating the effects of many synthetic (industrial and pharmaceutical) compounds called peroxisome proliferators (PPs) ${ }^{5}$. PPs influence both the size and number of peroxisomes, which perform various metabolic functions (peroxide derived respiration, beta oxidation of fatty acids, cholesterol metabolism, etc.) within the cell. It has been found that three PPAR isoforms exist: PPAR alpha, PPAR delta (also known as NUC1 or PPAR beta) and PPAR gamma. These are encoded by separated genes, perform separate functions and exhibit different tissue localization (Table 1). Like other nuclear receptors, after activation by ligand, PPARs bind a specific element in the promoter region of target genes. The dimerization of PPAR with RXR and the presence of coactivators are neccessary for the transcriptional activity of PPAR responsive element (PPRE) in DNA (Table 2). It is interesting, that not all PPRE in responsive genes mediate increase in transcription. For instance transthyretin, transferrin and/or some apolipoprotein genes are regulated negatively ${ }^{6,7,8,9}$. There is a wide spectrum of both exogenous and endogenous ligands of PPARs (Table 3 ) and it has been noted that their interaction with PPARs leads to various functions. PPARs play an important role during rodent 
Table1. Example of different tissue distribution of PPARs

\begin{tabular}{|l|l|l|l|l|}
\hline Isoform & Liver & Intestine & Spleen & Fat \\
\hline $\boldsymbol{\alpha}$ & ++++ & ++++ & + & - \\
\hline $\boldsymbol{\beta}$ & ++ & +++ & ++ & - \\
\hline $\boldsymbol{\gamma}$ & - & ++ & +++ & ++++ \\
\hline
\end{tabular}

Table 2. PPAR-interactive proteins

\begin{tabular}{|l|l|l|l|}
\hline Protein & & & \\
\hline Nuclear receptors & Coactivators & Corepressors & Others \\
\hline RXR & SRC-1/TIF2 & N-Cor/RIP 13 & c-Jun \\
\hline LXR alpha & P300/CBP & SMRT/TRAC & dUTPase \\
\hline SHP & PBP & RIP 140 & \\
\hline & PGC-1 & & \\
\hline & PGC-2 & & \\
\hline & ARA 70 & & \\
\hline & TSC 2 & & \\
\hline
\end{tabular}

Table 3. PPAR ligands

\begin{tabular}{|l|l|l|l|}
\hline \multicolumn{2}{|c|}{ Exogenous PPAR ligands } & \multicolumn{2}{c|}{ Endogenous PPAR ligands } \\
\hline \multicolumn{1}{|c|}{ PPAR $\alpha$} & \multicolumn{1}{|c|}{ PPAR $\gamma$} & \multicolumn{1}{c|}{ PPAR $\alpha$} & \multicolumn{1}{c|}{ PPAR $\gamma$} \\
\hline WY-14.643 & Indomethacin & Palmitic acid & Arachidonic acid \\
\hline Clofibrate & Ibuprofen & Stearic acid & $\begin{array}{l}\text { Eicosapentaenoic } \\
\text { acid }\end{array}$ \\
\hline Gemfibrozil & Piroxicam & Palmitoleic acid & PGJ2 \\
\hline Nafenopin & Pioglitazon & Oleic acid & 15 deoxy PG J12 \\
\hline Bezafibrate & Ciglitazon & Linoleic acid & \\
\hline & Englitazon & Arachidonic acid & \\
\hline & BRL-49653 & $\begin{array}{l}\text { Eicosapentaenoic } \\
\text { acid }\end{array}$ & \\
\hline
\end{tabular}

hepatocarcinogenesis, during inflammation, atherosclerosis development, lipid metabolism, diabetes, and they also have an important role in cancer ${ }^{10-15}$.

\section{Rodent hepatocarcinogenesis}

It has been found that increase in oxidative stress and proliferation (by decreasing the rate of apoptosis) due to activation of PPs by ligand binding to PPAR alpha leads to hepatocellular adenoma and carcinoma in rodents $\mathrm{s}^{6,10,11}$. However, there is no evidence that humans are at increased risk of liver cancer after chronic activation of PPs by PPAR alpha. Epidemiological studies have not revealed any risk of liver cancer development either in patients chronically exposed to the widely used hypolipidemic agents gemfibrozil and clofibrate (synthetic ligands of PPARs) ${ }^{16}$.

\section{Inflammation}

Even if recent opinion on the role PPARs during inflammation is controversial, it is generally accepted that PPARs can inhibit inflammatory responses and therefore they may be candidates for therapeutic intervention in some inflammatory disease ${ }^{15,17}$. Moreover, it has been found that activity of PPARs have effects on endothelial cells and therefore influence vascular response to various factors ${ }^{18}$.

\section{Atherosclerosis}

The effect of PPARs agonists on vascular smooth muscle cells, macrophages and vascular walls can modulate not only inflammatory but also atherosclerotic processes $^{17,19,20}$. PPAR may affect foam cell formation and modulate plaque stability. PPAR alpha decreases levels of pro-atherosclerotic proteins as fibrinogen and C-reactive protein and PPAR gamma may reduce expression of some metalloproteinases, implicated in plaque destabilization. On the other hand PPAR gamma are also able to stimulate uptake of oxidized LDL, which has pro-atherosclerotic effects ${ }^{12,13}$.

\section{Lipid metabolism and diabetes}

PPARs play a role in lipoprotein metabolism. Fibrates lower plasmatic levels of cholesterol and triacylglycerols and increase HDL by modulating the reverse cholesterol transport pathway. In consequence there is a decreased risk of coronary heart disease ${ }^{9}$. For this reason synthetic agonists of PPAR alpha (fibrates) are used in the treatment of hyperlipidemia. Agonists of PPAR gamma (thiazolidinediones and their derivatives rosiglitazone, troglitazone, pioglitazone, etc.) can improve insulin sensitivity and therefore have been used as efficient antidiabetics ${ }^{15}$. However, many of these antidiabetic compounds were withdrawn from the market due to liver toxicity and less toxic drugs have to be developed for succesful and harmless clinical use ${ }^{21}$.

\section{PPARs and cancer}

There is evidence that some PPARs can suppress the growth of different types of human cancer by distinct mechanisms including growth arrest, apoptosis and induction of differentiation ${ }^{6,13}$. Mutations of PPAR gamma in colon carcinoma lead to loss of ligand binding and suppression of cell growth. This may indicate that functional PPAR gamma is required for the normal growth properties of human colon cells ${ }^{22}$. However, the detailed signalling pathways leading to growth arrest 
and differentiation have not yet been completely elucidated. One possible mechanisms is upregulation of tumor suppresor PTEN by PPAR gamma agonists ${ }^{23}$. Overall, despite incomplete knowledge it is evident that PPAR ligands (agonists) may have potent anticancer potential and may serve as a rational basis in the therapy of some tumors or in their chemoprevention ${ }^{24-27}$. This is supported by in vitro studies: liposarcoma ${ }^{28}$, ovarian carcinoma ${ }^{29}$, breast carcinoma ${ }^{30-33}$, prostate carcinoma ${ }^{34-37}$, urinary bladder carcinoma ${ }^{38}$, some types of B lymphoma ${ }^{39}$, erythroleukemia ${ }^{40}$, non small cell lung cancer ${ }^{41}$, gastric ${ }^{42}$ and colon carcinomas ${ }^{22}$.

\section{PPARs and breast cancer}

It has been found that PPAR gamma, activated by various ligands (thiazolidinedione, gamma linoleic acid, omega-6 fatty acids) stimulates the terminal differentiation of breast cancer cell in vitro. Moreover, it seems that dietary fat may influence development of breast cancer and also that sensitivity to estrogen in breast cancer may be diminished by parallel expression of both ER and PPARs ${ }^{30-33}$. Taken together, the data indicate that PPAR gamma may play an important role in the regulation of growth and differentiation of the mammary gland and may be potentially used in therapy or chemoprevention of breast cancer.

\section{PPARs and glial tumors of the brain}

Since the changes of PPARs expression has been demonstrated in various types of cancers it is also interesting to explore the role of PPARs in glial tumors of the brain. It has been found that in contrast to normal astrocytes, the cell lines of malignant astrocytomas express higher levels of PPAR gamma ${ }^{43}$. Moreover, incubation of malignant astrocytoma cell lines with PPAR gamma agonists ciglitazone and 15-deoxy-Delta $(12,14)$ prostaglandin $\mathrm{J}(2)$ [15-deoxy $\mathrm{PGJ}(2)]$ reduced cell viability and increased apoptotic rate. This may suggest the role of PPAR in regulation of the apoptotic process in astroglial cells ${ }^{44}$. However, on the contrary, it has been reported that in cerebellar granule cells the PPAR gamma ligands troglitazone, ibuprofen and 15-deoxy PGJ(2) reduced inducible forms of nitric oxide synthase (iNOS) and reduced cell death ${ }^{45,46}$. We may hypothesize that the effect of PPARs on apoptosis and its signaling in the CNS depends on type of cell. Zhou X.P. et al. studied somatic mutations of the PPAR gamma gene in sporadic cases of glioblastoma multiforme ${ }^{47}$. They found over-represented polymorphic alleles at codons 12 and 449 among patients with glioblastoma compared to controls. Even if the precise consequence of this change is unknown, it raises the possibility of different effects of mutated and non-mutated forms of PPARs in glial tumors. It also seems that as with other tumors the potential of PPARs ligands in glial tumors may have therapeutic value.

\section{CONCLUSION}

Intensive study of PPARs during recent years has revealed that these nuclear receptors play an important role both in normal physiology and the pathology of various tissues. They participate in the regulation of lipid metabolism, they play an important role during rodent hepatocarcinogenesis, inflammation and development of atherosclerosis and/or diabetes, and they also have an important role in the regulation of growth and differentiation of cancer cells. It has been suggested that PPAR ligands with agonistic effects may have potent anticancer potential and may serve as a rational basis for therapy of some tumors or their chemoprevention. We can expect many promising results in this field in the near future.

\section{ACKNOWLEDGMENTS}

The work was supported in part by grants NC 6726-3/ 2001, FRVS 1471/2001 and MSM 151100001.

\section{REFERENCES}

1. Kumar R, Thompson EB (1999) The structure of the nuclear hormone receptors. Steroids 64, 310-319.

2. Kliewer SA, Lehmann JM, Wilson TM (1999) Orphan nuclear receptors: shifting endocrinology into reverse. Science 284, 757-760.

3. Heyman RA, Mangelsdorf DJ, Dyck JA, Stein RB, Eichele G, Evans RM, Thaller C (1992) 9-cis retinoic acid is a high affinity ligand for the retinoid X receptor. Cell 68, 397-406.

4. Sinal CJ, Tohkin M, Miyata M, Ward JM, Lambert G, Gonzales FJ (2000) Targeted disruption of the nuclear receptor FXR/BAR impairs bile acid and lipid homeostasis. Cell 102, 731-744.

5. Isseman I, Green S (1990) Activation of a member of the steroid hormone receptor superfamily by peroxisome proliferators. Nature 347, 645-650.

6. Corton JC, Anderson SP, Stauber A (2000) Central role of peroxisome proliferator-activated receptors in the actions of peroxisome proliferators. Annu. Rev. Pharmacol. Toxicol. 40, 491-518.

7. Braissant O, Foufelle F, Scotto C, Dauca M, Wahli W (1996) Differential expression of peroxisome proliferator-activated receptors (PPARs): tissue distribution of PPAR $-\alpha,-\beta$, and $-\gamma$ in the adult rat. Endocrinology 137, 354-366.

8. Mansen A, Guardiola-Diaz H, Rafter J, Branting C, Gustafsson, JA (1996) Expression of the peroxisome proliferator-activated receptor (PPAR) in the mouse colonic mucosa. Biochem. Biophys. Res. Commun. 222, 844-851.

9. Torra IP, Chinetti G, Duval C, Fruchart JC, Staels B (2001) Peroxisome proliferator-activated receptors: from transcriptional control to clinical practice. Curr. Opin. Lipidol. 12, 245-254.

10. Peters JM, Rusyn I, Rose ML, Gonzales FJ, Thurman RG (2000) Peroxisome proliferator activated receptor alpha is restricted to hepatic parenchymal cells, not Kupffer cells: implications for the mechanism of action of peroxisome proliferators in hepatocarcinogenesis. Carcinogenesis 21, 823-826.

11. Miller RT, Anderson SP, Corton JC, Cattley RC (2000) Apoptosis, mitosis and cyclophilin-40 expression in regressing peroxisome proliferator-induced adenomas. Carcinogenesis 21, 647-652. 
12. Li AC, Brown KK, Silvestre MJ, Willson TM, Palinski W, Glass CK (2001) Effects of PPAR $\gamma$ ligands on atherosclerosis. Quiagen News 1, 14-16.

13. Kersten S, Desvergne B, Wahli W (2000) Roles of PPARs in health and disease. Nature 405, 421-424.

14. Everett L, Galli A, Crabb D (2000) The role of hepatic peroxisome proliferator-activated receptors (PPARs) in health and disease. Liver 20, 191-199.

15. Murphy GJ, Holder JC (2000) PPAR-gamma agonists: therapeutic role in diabetes, inflammation and cancer. Trends Pharmacol. Sci. 21, 469-474.

16. Ashby J, Brady A, Elcombe CR, Elliott BM, Ishmael J, Odum J, Tugwood JD, Kettle S, Purchase IF (1994) Mechanistically-based human hazard assessment of peroxisome proliferator-induced hepatocarcinogenesis. Hum. Exp. Toxicol. 13, Suppl. 2: S1-117.

17. Moore KJ, Fitzgerald ML, Freeman MW (2001) Peroxisome proliferator-activated receptors in macrophage biology: friend or foe? Curr. Opin. Lipidol. 12, 519-527.

18. Plutzky J (2001) Peroxisome proliferator-activated receptors in endothelial cell biology. Curr. Opin. Lipidol. 12, 511-518.

19. Wakino S, Kintscher U, Liu Z, Kim S, Yin F, Ohba M, Kuroki T, Schonthal AH, Hsueh WA, Law RE (2001) PPAR gamma ligands inhibit mitogenic induction of p21Cip by modulating the PKC delta pathway in vascular smooth muscle cells. J. Biol. Chem. 276, 47650-47657.

20. Chinetti G, Fruchart JC, Staels B (2001) Peroxisome proliferatoractivated receptors (PPARs): nuclear receptors with functions in the vascular wall. Z. Kardiol. 90, Suppl. 3, 125-132.

21. Gale EAM (2001) Lessons from the glitazones: a story of drug development. Lancet 357, 1870-1875.

22. Sarraf P, Mueller E, Smith WM, Wright HM, Kum JB, Aaltonen LA, de la Chapelle A, Spiegelman BM, Eng C (1999) Loss-offunction mutation in PPAR gamma associated with human colon cancer. Mol. Cell 3, 799-804.

23. Patel L, Pass I, Coxon P, Downes CP, Smith SA, Macphee Ch (2001) Tumor suppresor and anti-inflammatory actions of PPAR gamma agonists are mediated via upregulation of PTEN. Curr. Biol. 11, 764-768.

24. Samid D, Wells M, Greene ME, Shen W, Palmer CNA, Thibault, A. (2000) Peroxisome proliferator-activated receptor gamma as a novel target in cancer therapy: binding and activation by an aromatic fatty acid with clinical antitumor activity. Clin. Cancer Res. 6, 933-941.

25. Brown PH, Lippman SM (2000) Chemoprevention of breast cancer. Breast Cancer Res. Treat. 62, 1-17.

26. Roberts-Thompson SJ (2000) Peroxisome proliferator-activated receptors in tumorigenesis: targets of tumour promotion and treatment. Immunol. Cell Biol. 78, 436-441.

27. Lippman SM, Lotan R (2000) Advances in the development of retinoids as chemopreventive agents. J. Nutr. 130, 479S-482S.

28. Demetri GD, Fletcher CDM, Mueller E, Sarraf P, Naujoks R, Campbell N, Spiegelman BM, Singer S (1999) Induction of solid tumor differentiation by the peroxisome proliferator-activated receptor-gamma ligand troglitazone in patients with liposarcoma. Proc. Natl. Acad. Sci. USA 96, 3950-3956.

29. Ferrandina G, Melichar B, Loercher A, Verschraegen CF, Kudelka AP, Edwards CL, Scambia G, Kavanagh JJ, Abbruzzese JL, Freedman LS (1997) Growth inhibitory effects of sodium phenylacetate (NSC 3039) on ovarian carcinoma cells in vitro. Cancer Res. 57, 4309-4315.

30. Rubin GL, Zhao Y, Kalus AM, Simpson ER. (2000) Peroxisome proliferator-activated receptor gamma ligands inhibit estrogen biosynthesis in human breast adipose tissue: possible implications for breast cancer therapy. Cancer Res. 60, 1604-1608.

31. Mueller E, Sarraf P, Tontonoz P, Evans RM, Martin KJ, Zhang M, Fletcher C, Singer S, Spiegelman BM (1998) Terminal differentiation of human breast cancer through PPAR gamma. Mol. Cell 1, 465-470.

32. Jiang WG, Redfern A, Bryce RP, Mansel RE (2000) Peroxisome proliferator activated receptor-gamma (PPAR-gamma) mediates the action of gamma linoleic acid in breast cancer cells. Prostaglandins Leukot. Essent. Fatty Acids 62, 119-127.

33. Thoennes SR, Tate PL, Price TM, Kligore MW (2000) Differential transcriptional activation of peroxisome proliferator-activated receptor gamma by omega-3 and omega- 6 fatty acids in MCF-7 cells. Mol. Cell Endocrinol. 160, 67-73.

34. Collet GP, Betts AM, Johnson MI, Pulimood AB, Cook S, Neal DE, Robson CN (2000) Peroxisome proliferator-activated receptor alpha is an androgen-responsive gene in human prostate and is highly expressed in prostatic adenocarcinoma. Clin. Cancer Res. 6, 3241-3248.

35. Butler R, Mitchell SH, Tindall DJ, Young CY (2000) Nonapoptotic cell death associated with S-phase arrest of prostate cancer cells via the peroxisome proliferator-activated receptor gamma ligand, 15-deoxy-delta12,14-prostaglandin J2. Cell Growth Differ. 11, 49-61.

36. Kubota T, Koshizuka K, Williamson EA, Asou H, Said JW, Holden S, Miyoshi I, Koeffler HP (1998) Ligand for peroxisome proliferator-activated receptor gamma (troglitazone) has potent antitumor effect against human prostate cancer both in vitro and in vivo. Cancer Res. 58, 3344-3352.

37. Guan YF, Zhang YH, Breyer RM, Davis L, Breyer MD (1999) Expression of peroxisome proliferator-activated receptor gamma (PPAR gamma) in human transitional bladder cancer and its role in inducing cell death. Neoplasia 1, 330-339.

38. Padilla J, Kaur K, Harris SG, Phipps RP (2000) PPAR-gammamediated regulation of normal and malignant $\mathrm{B}$ lineage cells. Ann. N. Y. Acad. Sci. 905, 97-109.

39. Hirase N, Yanase T, Mu Y, Muta K, Umemura T, Takayanagi R, Nawata H (2000) Thiazolidinedione suppresses the expression of erythroid phenotype in erythroleukemia cell line K562. Leuk. Res. 24, 393-400.

40. Chang TH, Szabo E (2000) Induction of differentiation and apoptosis by ligands of peroxisome proliferator-activated receptor gamma in non-small cell lung cancer. Cancer Res. 60, 1129-1138.

41. Sato H, Ishihara S, Kawashima K, Moriyama N, Suetsugu H, Kazumori H, Okuyama T, Rumi MA, Fukuda R, Nagasue N, Kinoshita Y (2000) Expression of peroxisome proliferator-activated receptor (PPAR)gamma in gastric cancer and inhibitory effects of PPARgamma agonists. Br. J. Cancer 83, 1394-1400.

42. Gupta RA, Tan J, Krause WF, Geraci MW, Willson TM, Dey SK, DuBois RN (2000) Prostacyclin-mediated activation of peroxisome proliferator-activated receptor delta in colorectal cancer. Proc. Natl. Acad. Sci. USA 97, 13275-13280.

43. Nwankwo JO, Robbins ME (2001) Peroxisome proliferator-activated receptor-gamma expression in human malignant and normal brain, breast and prostate-derived cells. Prostaglandins Leukot. Essent. Fatty Acids 64, 241-245.

44. Chattopadhyay N, Singh DP, Heese O, Godbole MM, Sinohara T, Black PM, Brown EM (2000) Expression of peroxisome proliferator-activated receptors (PPARS) in human astrocytic cells: PPARgamma agonists as inducers of apoptosis. J. Neurosci. Res. 61, 67-74.

45. Heneka MT, Feinstein DL, Galea E, Gleichmann M, Wullner U, Klockgether T (1999) Peroxisome proliferator-activated receptor gamma agonists protect cerebellar granule cells from cytokineinduced apoptotic cell death by inhibition of inducible nitric oxide synthase. J. Neuroimmunol. 100, 156-168.

46. Heneka MT, Klockgether T, Feinstein DL (2000) Peroxisome proliferator-activated receptor-gamma ligands reduce neuronal inducible nitric oxide synthase expression and cell death in vivo. J. Neurosci. 20, 6862-6867.

47. Zhou XP, Smith WM, Gimm O, Mueller E, Gao X, Sarraf P, Prior TW, Plass C, von Deimling A, Black PM, Yates AJ, Eng C (2000) Over-representation of PPAR gamma sequence variants in sporadic cases of glioblastoma multiforme: preliminary evidence for common low penetrance modifiers for brain tumour risk in the general population. J. Med. Genet. 37, 410-414. 